\title{
ANALISIS PENGEMBANGAN LEMBAR KERJA SISWA (LKS) DENGAN KONTEKS ETNOMATEMATIKA AKTIVITAS PENANAMAN BUAH NAGA
}

\author{
${ }^{1}$ Elok Kurnia Lailatul Fitriyani, ${ }^{2}$ Dimas Danar Septiadi \\ ${ }^{1}$ IAIN Jember. J1. Mataram No. 1 Mangli Jember, Telp (0331) 487550, 427005 /Fax (0331) 427005, \\ ${ }^{2}$ IAIN Jember. Jl. Mataram No. 1 Mangli Jember, Telp (0331) 487550, 427005 /Fax (0331) 427005 \\ e-mail: ${ }^{1}$ 1319daila@gmail.com, ${ }^{2}$ septiadi.dimasd@yahoo.com
}

\begin{abstract}
Abstrak
Pembelajaran adalah proses komunikasi antara pembelajar, pengajar dan bahan ajar. LKS yaitu bahan ajar yang diterapkan guru dalam mentransfer informasi dengan bentuk yang lebih praktis, menarik dan utamanya siswa dapat dipermudah dalam menerima informasi. Realita yang sering terjadi dilapangan yaitu kurangnya motivasi belajar siswa terhadap proses pembelajaran pada materi SPLDV, kurangnya pemahaman siswa siswa dalam memahami soal cerita yamg berkaitan dengan SPLDV, kurang tahunya keterkaitan matematika dengan permasalahan sehari-hari. Rumusan masalah yang digunakan yaitu 1) Bagaimana pengembangan LKS dengan konteks aktivitas penanaman buah naga?, 2) Bagaimana kajian etnomatematika dengan konteks aktivitas penanaman buah naga?. Penelitian ini merupakan penelitian pengembangan atau research and development $(\mathrm{R}$ \& D). Pengembangan dilakukan dengan menggunakan tahapan Borg and Gall yang dimodifikasi menjadi 5 fase. Adapun tahapan yang diperoleh yaitu 1) Proses pengembangan LKS berdasarkan tahapan Borg and Gall, 2) Kajian etnomatematika berdasarkan hasil penelitian penanaman buah naga dan aktivitas etnomatematika yang diperoleh antara lain seperti biaya pembelian kabel, lampu, batang buah naga, pupuk pertanian, ongkos kerja, biaya beton, dan lain sebagainya.
\end{abstract}

Kata Kunci: Lembar Kerja Siswa, Etnomatematika Aktivitas Penanaman Buah Naga

\begin{abstract}
Learning is a process of communication between learners, teachers and teaching materials. LKS is a teaching material that is applied by the teacher in transferring information in a more practical, interesting form and especially for students to receive information. The reality that often occurs in the field is the lack of student motivation towards the learning process, the lack of understanding of students in understanding story questions, the lack of knowledge of the relationship between mathematics and everyday problems. The formulation of the problem used is 1) How is the development of worksheets with the context of dragon fruit planting activities? 2) How is the ethnomatematic study with the context of dragon fruit planting activities? This research is research and development (R \& D). The development was carried out using Borg and Gall stages which were modified into 5 phases. The stages obtained are 1) The suitability of the LKS development with the Borg and Gall stages, 2) The ethnomatematic studies obtained from this research include the cost of purchasing cables, lamps, dragon fruit stalks, agricultural fertilizers, labor costs, concrete costs, and so on.
\end{abstract}

Keywords: Student Worksheets, Ethnomatematics of Dragon Fruit Planting Activities

\section{PENDAHULUAN}

Pembelajaran adalah proses komunikasi antara pembelajar, pengajar dan bahan ajar. ${ }^{1}$ Pembelajaran bersifat interaktif dan komunikatif antara guru dengan siswa sumber belajar dan lingkungan, sehingga menciptakan kondisi belajar siswa, baik di dalam kelas atau di luar

\footnotetext{
${ }^{1}$ Hujair Ah Sanaky, Media Pembelajaran Interaktif-Inovatif (Yogyakarta: Kaukaba Dipantara, 2015), 3.
} 
kelas maupun dihadiri guru secara fisik atau tidak guna untuk menguasai kompetensi yang telah ditentukan. ${ }^{2}$ Proses pembelajaran dapat mewujudkan pencapaian penguasaan kompetensi. Pencapaian penguasaan kompetensi dapat terjadi pada pembelajaran salah satunya dapat melalui pemberian lembar kerja siswa pada siswa.

Lembar kerja siswa adalah panduan yang diberikan kepada siswa yang dapat digunakan untuk melakukan penyelidikan atau pemecahan masalah sehingga menemukan konsep materi yang dipelajari. Sebaiknya LKS dibuat sendirinya oleh guru dengan desain yang telah ditetapkan Depdiknas. Desain LKS terdiri dari 6 komponen yang terdiri dari judul, petunjuk belajar, kompetensi yang dicapai, informasi yang mendukung, tugas-tugas berupa soal dan langkah-langkah kerja dan penilaian. ${ }^{3}$ Soal-soal yang digunakan dalam LKS dapat berupa soal yang berkaitan dengan permasalahan kehidupan sehari-hari yang menjadi budaya di masyarakat.

LKS ini dibuat berdasarkan realita permasalahan pada proses pembelajaran. Adapun realita permasalahan pada proses pembelajaran yaitu kurangnya bahan ajar yang diberikan kepada siswa, guru hanya memberikan tugas secara langsung setiap hari, kurangnya pemahaman konsep matematika serta pengaplikasiannya dan siswa cenderung bosan serta kurang bersemangat pada saat proses pembelajaran di kelas dan masih ada siswa yang tidak mengerjakan tugas. LKS ini dapat diterapkan oleh guru pada seluruh mata pelajaran, salah satunya dapat diterapkan pada mata pelajaran matematika.

Matematika merupakan salah satu bidang keilmuan yang memiliki peran penting baik disekolah maupun dalam kehidupan sehari-hari. Penerapan matematika dalam bidang pertanian dapat dilihat dari berbagai aktivitas yang dilakukan oleh para petani. Aktivitas petani yang dimulai dari pembibitan sampai pembuahan telah menerapkan materi matematika yang berkaitan dengan cara mengelompokan, menghitung, mengukur, merancang bangunan atau alat dan menentukan lokasi. ${ }^{4}$ Salah satu contoh aktivitas yang memuat konsep matematika yaitu pada aktivitas penanaman buah naga dengan menggunakan lampu di daerah Kecamatan Bangorejo Kabupaten Banyuwangi. Kebiasaan yang dilakukan para petani di daerah Banyuwangi khususnya Kecamatan Bangorejo ini dengan seiringnya waktu menjadi suatu kebudayaan para petani petani di daerah ini.

\footnotetext{
${ }^{2}$ Zainal Arifin, Evaluasi Pembelajaran (Bandung: PT Remaja Rosdakarya, 2014), 10.

${ }^{3}$ Untari Octavia Norsanty dan Zahra Chairani, "Pengembangan Lembar Kerja Siswa (LKS) Materi Lingkaran Berbasis Pembelajaran Guided Discovery untuk Siswa SMP Kelas VIII," Jurnal Pendidikan Matematika 2, no.1 (2016): 13.

${ }^{4}$ Mila Afriana Agustin, “Aktivitas Etnomatematika Petani Kopi Di Daerah Sidomulyo Jember sebagai Lembar Proyek Siswa" (Skripsi, Universitas Jember, 2018), 3.
} 
Aktivitas kebudayaan dan matematika yang saling berhubungan bisa disebut dengan etnomatematika. Istilah etnomatematika pertama dicetuskan dan dikembangkan oleh matematikawan Brazil bernama Ubiratan D'Ambrosio. Menurut D'Ambrosio etnomatematika adalah suatu studi tentang pola hidup, kebiasaan atau adat istiadat dari suatu masyarakat di suatu tempat yang memiliki kaitan dengan konsep matematika namun tidak disadari sebagai bagian dari matematika oleh masyarakat tersebut. ${ }^{5}$ Dengan adanya gagasan D'Ambrosio tersebut menjelaskan sebab munculnya etnomatematika yang disebabkan dari aktivitas matematika yang dipengaruhi oleh kegiatan masyarakat dan budaya masyarakat.

Adanya keterkaitan aktivitas kebudayaan dan matematika bisa dilakukan pengembangan suatau bahan ajar yang dapat membantu siswa dalam mempermudah pembelajaran terhadap konsep-konsep matematika. Cara yang sangat penting dilakukan dengan cara mempersiapkan rancangan Lembar kerja siswa. Rancangan tersebut dapat dilakukan dengan menggunakan desain yang unik dan menarik. Hal ini dilakakukan agar LKS yang buat akan dapat memotivasi siswa dalam belajar. Selain itu, juga dalam pemberian LKS pada mata pelajaran dapat mempermudah siswa dalam memahami materi yang diberikan dengan tampilan yang lebih ringkas, menarik dan kaya akan tugas.

Berdasarkan data di atas dikarenakan kurangnya penggunaan bahan ajar LKS pada proses pembelajaran diatas, maka peneliti tertarik untuk melakukan penelitian tentang “Analisis Lembar Kerja Siswa (LKS) dengan Konteks Etnomatematika Aktivitas Penanaman Buah Naga" dengan tujuan agar dapat menumbuhkan siswa untuk berpikir rasional.

\section{METODE PENELITIAN}

Jenis penelitian yang digunakan dalam penelitian ini yaitu penelitian dan pengembangan (Research and Development) atau R \& D model Borg and Gall yang memiliki 10 fase. $^{6}$ Namun pada penelitian ini diadaptasi oleh peneliti yang semula 10 fase menjadi 5 fase yaitu (1) Tahap penelitian dan pengumpulan informasi awal, (2) Tahap perencanaan, (3) Tahap pengembangan produk, (4) Tahap uji coba produk, (5) Tahap revisi. Peneliti melakukan pengembangan hanya melalui 5 tahap yang tidak sampai pada proses desiminasi. Proses pada penelitian ini hanya dilakukan sampai desiminasi karena memiliki pertimbangan

\footnotetext{
5 Indri Aprilianti., dkk, "Etnomatematika pada Aktivitas Petani Kakao Desa Temuasri Sempu Banyuwangi sebagai Bahan Ajar Siswa," Saintifica 21, no. 1 (Januari, 2019): 2.

${ }^{6}$ Amir Hamzah.. "Metode Penelitian \& Pengembangan (Research and Development) Uji Produk Kuantitatif dan Kualitatif Proses dan Hasil”. (Malang: Literasi Nusantara, 2019).
}

Analisis pengembangan lembar kerja siswa (LKS) dengan konteks etnomatematika aktivitas 
waktu dan fokus penelitian hanya pada hasil kevalidan LKS saja. Pada penelitian ini membahas terkait kajian etnomatematika. Adaun kajian etnomatematika yang digunakan yaitu etnomatematika penanaman buah naga dengan menggunakan lampu di daerah Bangorejo Banyuwangi.

\section{HASIL DAN PEMBAHASAN}

Peneliti terdahulu menjadi salah satu acuan peneliti dalam melakukan penelitian sehingga peneliti dapat memperkaya teori yang digunakan dalam mengkaji penelitian yang dilakukan. Dari penelitian terdahulu, peneliti tidak menemukan penelitian dengan judul yang sama seperti judul penelitian yang dilakukan peneliti. Namun peneliti mengangkat beberapa penelitian sebagai referensi dalam memperkaya bahan kajian pada penelitian oleh peneliti. Adapun hasil dari kajian terdahulu yang diperoleh dari jurnal pertama yang berjudul Pengembangan Lembar Kerja Siswa (LKS) Materi Lingkaran Berbasis Pembelajaran Guided Discovery untuk Siswa SMP Kelas VIII yang dilakukan oleh Untari Octavia Norsanty dan Zahra Chairani yaitu Pengembangan LKS materi lingkaran berbasis pembelajaran guided discovery ditinjau dari aspek kevalidan, kepraktisan, dan keefektivan memiliki kategori baik dan layak. Sedangkan perbedaan pada bulan Januari - April 2016 dan menghasilkan produk berupa LKS materi lingkaran berbasis pembelajaran guided discovery yang mengacu pada model pengembangan ADDIE yang terdiri dari lima tahap, yaitu Analysis, Design, Development, Implementation, dan Evaluation. Adapun hasil dari jurnal kedua yang berjudul pengembangan lembar kerja siswa berbasis pendekatan kontekstual pada materi lingkaran untuk siswa SMP yang dilakukan oleh Reva Gitriani, dkk pada tahun 2018 yaitu pengembangan LKS materi lingkaran berbasis pembelajaran kontekstual ditinjau dari aspek kevalidan, kepraktisan, dan keefektivan memiliki kategori sangat baik dan layak. Sedangkan perbedaan dari peneliti LKS untuk siswa SMP materi lingkaran dan menggunakan model pengembangan ADDIE yang terdiri dari lima tahap yaitu analysis, design, development, implementation, dan evaluation dan pendekatan yang digunakan yaitu berbasis pendekatan kontekstual. Hasil dari jurnal ketiga yang berjudul pengembangan LKS untuk metode penemuan terbimbing pada pembelajaran matematika kelas VIII di SMP Negeri 18 Palembang yang dilakukan oleh Farida Aryani dan Cecil Hiltrimartin yaitu LKS yang dikembangkan efektif meningkatkan aktivitas belajar siswa. Secara keseluruhan ada 34 dari $40(85 \%)$ siswa yang telah memiliki kemampuan baik serta memiliki potensial efek terhadap pembelajaran untuk metode penemuan terbimbing. Selain itu siswa mendapat nilai minimal 7,2 dengan jumlah 34 siswa, dengan ini berarti di kelas uji coba memiliki potensial efek 
terhadap kemampuannya. Adapun perbedaannya yaitu penelitian oleh Farida Aryani dan Cecil Hiltrimartin dilaksanakan pada tahun 2009. Pengembangan atau development research yang digunakan tipe formative research untuk menghasilkan LKS untuk metode penemuan terbimbing. Adapun persamaan dari ketiga kajian terdahulu yaitu mengembangkan bahan ajar berupa LKS pada materi tertentu ditingkat tingkat SMP.

Berdasarkan hasil kajian peneliti di atas penelitian yang dilakukan memiliki fokus penelitian yang berbeda. Perbedaan tersebut dapat dilihat pada tabel di atas. Seperti pada hasil kajian pada ketiga jurnal tersebut fokus penelitian yang dibuat berbeda dengan penelitian yang ditulis oleh peneliti. Peneliti melakukan penelitian memiliki fokus penelitian yaitu untuk mengembangkan lembar kerja siswa yang berkaitan dengan etnomatematika dengan tujuan untuk memotivasi belajar siswa untuk melatih berpikir rasional. Selain itu juga dapat membantu pola pikir anak tentang adanya aplikasi matematika dalam kehidupan seharihari. dengan mengambil sampel kelas VIII di SMP Ainul Yaqin tahun ajaran 2019/2020.

Dalam penyajian data uji coba pada penelitian pengembangan LKS matematika ini mengacu pada model pengembangan Borg and Gall yang dimodifikasi menjadi 5 tahap atau fase. Adapun tahap-tahap yang dilakukan pada pengembangan LKS matematika ini sebagai berikut:

\section{Penelitian dan Pengumpulan Informasi Awal}

Tahap pertama dalam prosedur penelitian dan pengembangan adalah melakukan penelitian dan pengumpulan informasi awal. Pada penelitian dan pengumpulan informasi awal dilakukan untuk menentukan materi dan menganalis kebutuhan yang akan diperlukan sebagai dasar proses penelitian dan pengembangan produk. Materi yang dipilih dalam penelitian ini adalah materi sistem persamaan linear dua variabel (SPLDV). SPLDV ini merupakan salah satu mata pelajaran yang harus ditempuh oleh siswa tingkat SMP. Penentuan materi SPLDV dilakukan dengan tujuan dapat membantu siswa kelas VIII SMP dalam memecahkan permasalahan sehari-hari dengan mudah, memberikan pengalaman belajar, mampu membantu siswa dapat berpikir rasional. Berdasarkan observasi awal masih banyak siswa yang merasa kesulitan dalam memecahkan permasalahan dengan SPLDV, siswa masih sulit membedakan metode penyelesaian SPLDV yang digunakan, kurang antusias dalam belajar matematika. Sikap yang dimunculkan siswa pada saat proses pembelajaran yaitu kurang terlibatnya siswa dalam pembelajaran dan media yang digunakan masih menyulitkan siswa.

Analisis pengembangan lembar kerja siswa (LKS) dengan konteks etnomatematika aktivitas 
Berdasarkan data di atas maka diperlukan adanya inovasi baru dalam mempermudah belajar siswa. Inovasi ini diwujudkan dalam bentuk "Lembar Kerja Siswa" atau biasa disebut LKS namun memiliki muatan yang berbeda dengan LKS umumnya. LKS ini dikembangkan dengan menyesuaikan kurikulum pada sekolah tersebut yaitu LKS berbasis model problem based learning (PBL) dengan harapan siswa dapat belajar tentang matematika yang berkaitan dengan kehidupan sehari-hari. Selain itu, dapat menumbuhkan sikap aktif berdiskusi, bekerja sama, tanggung jawab, tetiti, mandiri, percaya diri. Dengan begitu siswa dapat menyelesaikan tugasnya dengan baik dan hasil belajarnya meningkat khususnya pada mata pelajaran SPLDV. Akhirnya, pencapaian tujuan pembelajaran dapat tercapai dan dapat menerapkan materi SPLDV dalam kehidupan sehari-hari.

Pada tahap ini juga dilakukan observasi mengenai etnomatematika pada aktivitas penanaman buah naga. Data yang diperoleh oleh peneliti diambil secara langsung kepada petani buah naga yang melakukan penanaman dengan menggunakan lampu di daerah Bangorejo. Dalam pengambilan data ini peneliti memilih tiga responden yang bernama Bapak Andik, Bapak Rahmat dan Bapak Dhori. Dari hasil observasi langsung ini didapatkan rata-rata mengenai etnomatematika. Adapun etnomatematika yang didapatkan dari hasil observasi salah satunya yaitu dalam penggunaan jenis lampu yang biasa digunakan adalah lampu Renesola dengan daya 12 dan 16 watt. Harga lampu Renesola dengan daya 12 watt yaitu sebesar Rp19.000,00, sedangkan lampu Renesola dengan daya 16 watt sebesar Rp21.000,00. Berdasarkan pernyataan para petani rata-rata mengemukakan alasan melakukan penanaman buah naga dengan cara menggunakan lampu yaitu dengan tujuan agar dapat mendapatkan hasil yang lebih maksimal, bisa mencapai keuntungan yang berkali-kali lipat. Penggunaan lampu pada penanaman buah naga dilakukan dengan dua shif waktu. Adapun batasan dua shif waktu yang biasa digunakan yaitu shif pertama dimulai pada pukul 17.00-00.00 WIB dan shif kedua mulai jam 00.00-05.00 WIB. Pengaturan shif ini bisa disetel sendiri pada spidometer sesuai yang diinginkan para petani. Untuk lebih jelasnya bisa dilihat pada gambar berikut: 


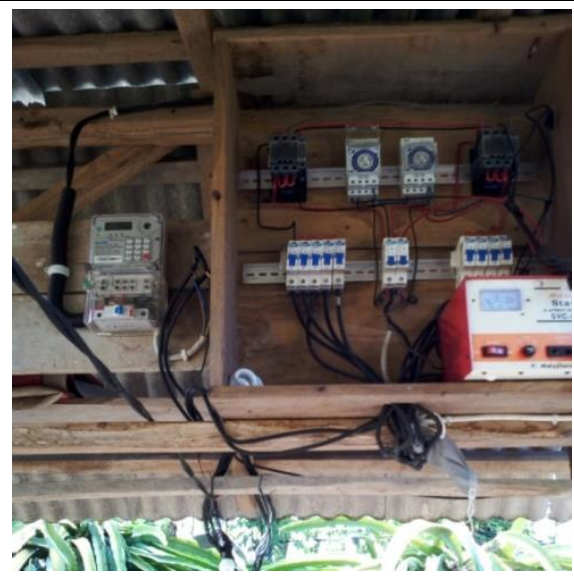

Gambar 4.1

Gambar Spidometer Tanaman Buah Naga
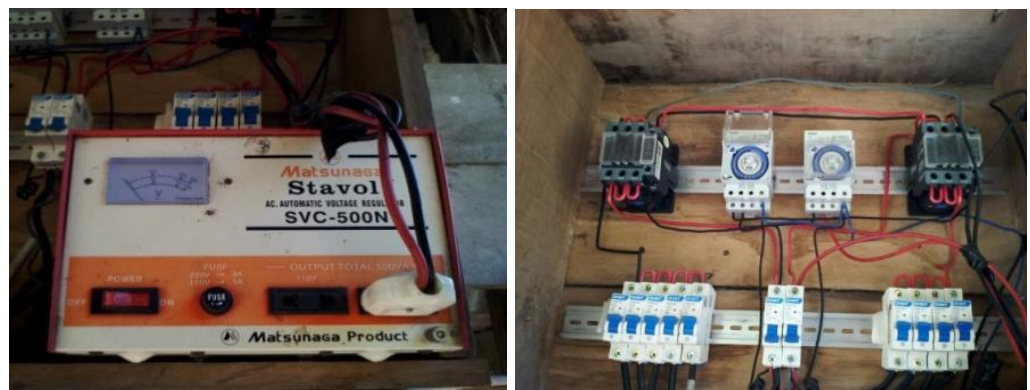

Gambar 4.2

Gambar Pengatur Tegangan Listrik dan Saklar Spidometer Tanaman Buah Naga

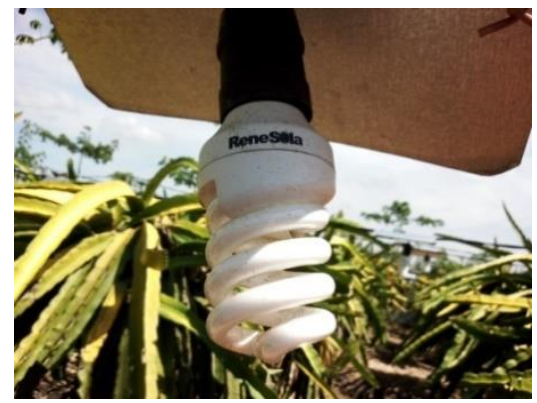

Gambar 4.3

Lampu Renesola

Selain itu, pupuk yang sering digunakan petani yaitu Poska dan ZA, dengan perbandingan sebanyak 2 : 1 (Pupuk subsidi). Pupuk yang digunakan bisa pupuk subsidi atau non subsidi. Harga pupuk subsidi lebih murah dibandingkan harga pupuk non subsidi. Harga pupuk Poska 1 kw yang Subsidi sebesar Rp230.000,00 dan pupuk ZA 1 kw sebesar Rp180.000,00. Untuk lebih jelasnya bisa dilihat pada gambar berikut:

Analisis pengembangan lembar kerja siswa (LKS) dengan konteks etnomatematika aktivitas penanaman buah naga Fitriyani, Septiadi 


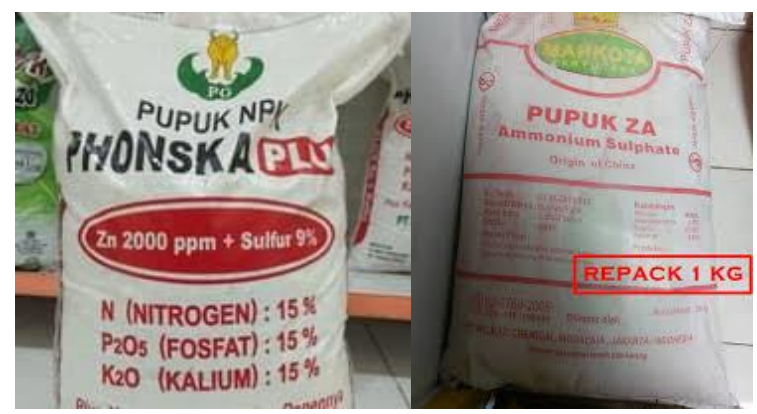

Gambar 4.4

Pupuk Poska dan ZA

Tanaman buah naga ini merupakan tanaman yang berumur panjang. Siklus produktivitasnya bisa mencapai 15-20 tahun. Pada masa awal pemanenan biasanya hasil tidak berlangsung secara optimal. Hal ini dapat dilihat pada satu tanaman bisa menghasilkan $1 \mathrm{~kg}$ buah naga yang dalam 1 tiang terdapat 4 tunas. Dari realita tersebut, merupakan estimasi untuk satu pohon buah naga, jika pohon buah naga sebanyak 1.600 tongkat/ha maka dapat menghasilkan $\pm 6-7$ ton buah naga dalam sekali musim panen. Jika bibit baik, maka buah naga bisa mencapai 50 ton/ha dalam sekali panen.

Proses penanaman buah naga itu terjadi pada dua musim yaitu musim naga dan musim lampu. Musim naga merupakan musim munculnya bunga dengan sendirinya sehingga memunculkan hasil buah naga yang maksimal. Cuaca dikatakan stabil dimulai pada bulan April-Agustus. Biasanya pada musim ini harga jual buah naga rendah atau sedang, biasanya harganya berkisar kurang lebih dari Rp5000,00, dari data tersebut petani mendapatkan keuntungan yang kurang maksimal. Sedangkan musim lampu merupakan musim di luar buah naga dapat memunculkan bunga dengan bantuan buatan seperti penggunaan lampu. Hal ini dilakukan agar mendapatkan hasil yang maksimal. Musim ini berlangsung pada bulan Februari-Maret. Biasanya pada musim ini harga jual buah naga tinggi sehingga petani bisa mendapatkan keuntungan hingga berkali-kali lipat. Sedangkan bunga buah naga ini mekar selama tujuh hari tujuh malam. Proses penyerbukan buah naga terjadi pada masa-masa tersebut. Penyerbukan ini bisa dilakukan dengan penyerbukan secara alami melalui angin dan serangga atau bisa dengan cara buatan yang melalui bantuan manusia.

\section{Perencanaan}

Proses yang dilakukan setelah menganalisis kebutuhan dan pemilihan materi melalui observasi lapangan yaitu perencanaan. Adapun langkah yang dilakukan pada tahap ini yaitu pengumpulan buku yang mendukung terwujudnya LKS berbasis problem based 
learning yaitu LKS, pemilihan desain yang sesuai, pemilihan layout sesuai dengan karakteristik siswa SMP, pengembangan desain LKS, pengumpulan buku yang berkaitan dengan materi SPLDV, pengembangan materi SPLDV, pengembangan draf product serta menyiapkan angket yang digunakan untuk menvalidasi produk LKS kepada validator ahli desain, ahli konten matematika dan ahli pendidikan matematika. Adapun fitur-fitur yang terdapat pada LKS dapat dilihat pada gambar fitur di bawah ini.

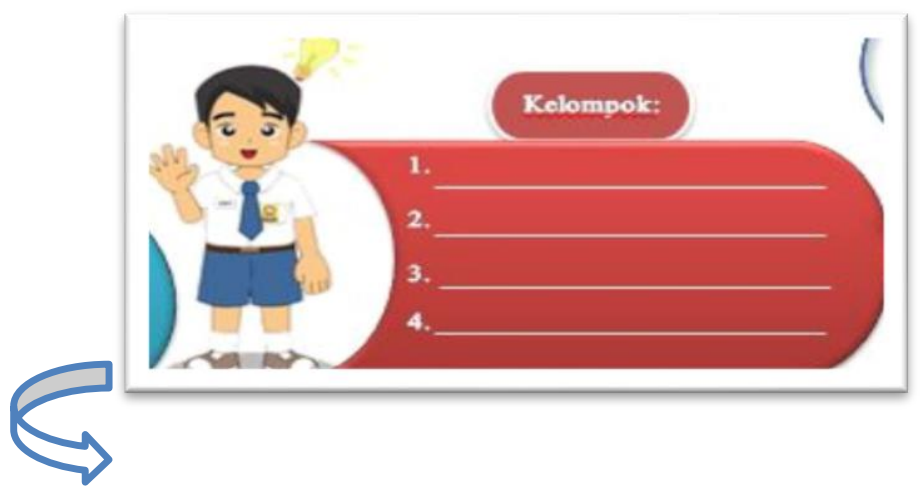

Pemilihan fitur anak SMP dengan maksud LKS matematika ini ditujukan untuk siswa tingkat SMP/MTS sederajat.

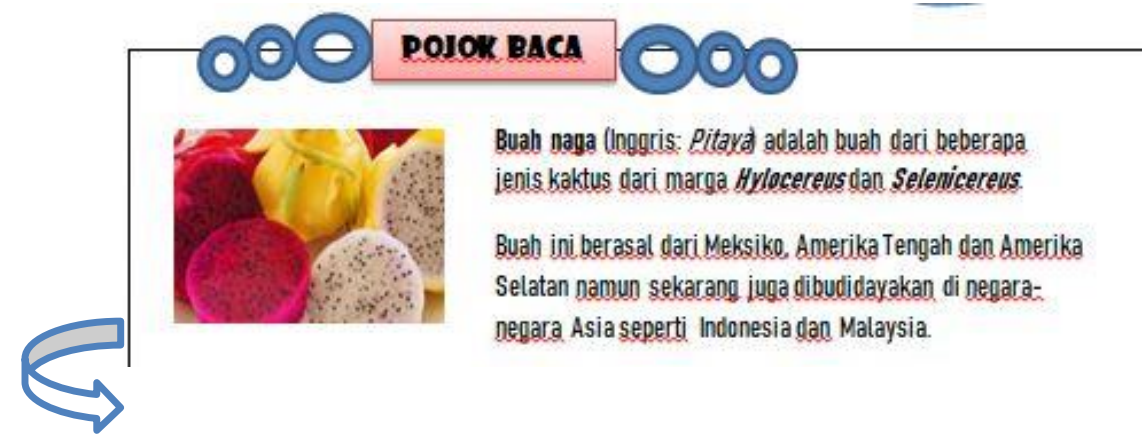

Gambar 4.5

Contoh Fitur Kolom Nama pada LKS

Pojok baca di atas dimaksudkan agar siswa dapat menambah wawasan mengenai istilah nama buah naga.

Analisis pengembangan lembar kerja siswa (LKS) dengan konteks etnomatematika aktivitas 


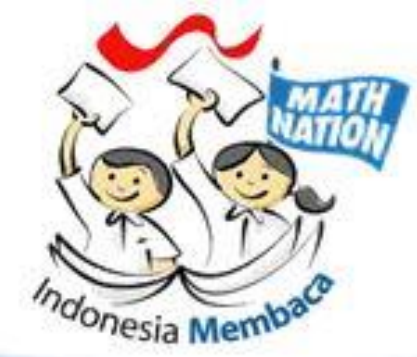

Penggunaan fitur Indonesia math nation ini dengan maksud untuk memberikan motivasi siswa untuk membudayakan gemar baca terutama pada materi matematika agar mampu menjadi negara matematika.

Gambar 4.6

Contoh Fitur Pojok Baca pada LKS

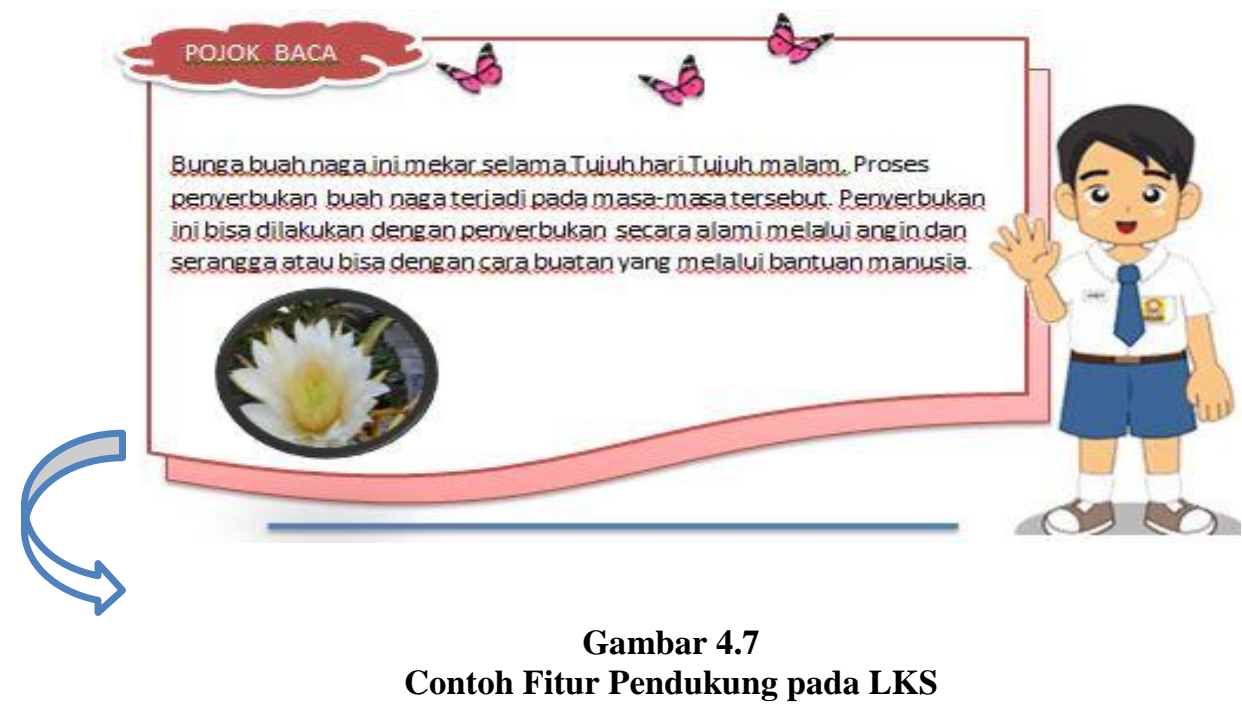

Pojok baca di atas dibuat sebagai pelengkap informasi mengenai penyerbukan bunga buah naga.

\section{Penyajian Produk Pengembangan LKS}

Pengembangan produk $\mathrm{R} \& \mathrm{D}$ disesuaikan dengan ketentuan penyusunan LKS. Adapun pedoman penyusunan LKS ini, ketentuan yang harus dicantumkan diantaranya judul atau materi yang dikembangkan harus berintikan KD yang harus dicapai siswa. Dalam LKS produk R \& D sudah dilengkapi KD, indikator, tujuan pembelajaran, fakta terkait etnomatematika buah naga dan soal-soal yang berkaitan dengan aktivitas penanaman buah naga. Dalam penyajian LKS ini dibuat dengan berbasis model problem based learning.

Berikut penyajian secara objektif dan tuntas prototype product pengembangan LKS matematika berbasis problem based learning untuk kelas VIII semester ganjil sebagai upaya meningkatkan kemampuan berpikir rasional siswa, agar lebih jelas dan mudah dapat dilihat pada lampiran produk (Lampiran 3). 


\section{a. Cover (Sampul)}

Sampul produk R \& D LKS matematika ini terdiri dari dua jenis yaitu sampul depan dan sampul belakang. Sampul depan berisi judul LKS dan sasaran pengguna yakni kelas VIII semester ganjil, materi, identitas pengguna LKS, gambar pendukung materi matematika, kurikulum 2013 edisi revisi 2017 dan logo IAIN Jember. Kurikulum 2013 edisi revisi 2017 ini menandakan LKS yang dibuat disesuaikan dengan kurikulum yang sedang diterapkan sekolah. Latar desain warna yang dibuat berwarna putih dipadu warna biru dengan variasi berbagai macam warna lainya, perpaduan warna ini bertujuan agar LKS terlihat lebih menarik dan tidak monoton. Sedangkan tulisan "LKS MATH" dibuat dengan font yang berbeda dengan variasi warna hijau dan ungu dengan motif garis-garis dan tulisan SPLDV berwarna putih. Sedangkan pada tulisan yang lain menyesuaikan warnanya sehingga perpaduan terlihat menarik. Pada sampul depan ditampilkan logo IAIN Jember digunakan sebagai identitas peneliti. Adapun untuk sampul belakang warna yang digunakan disesuaikan dengan warna sampul depan yaitu warna putih. Berikut tampilan cover LKS berbasis model problem based learning

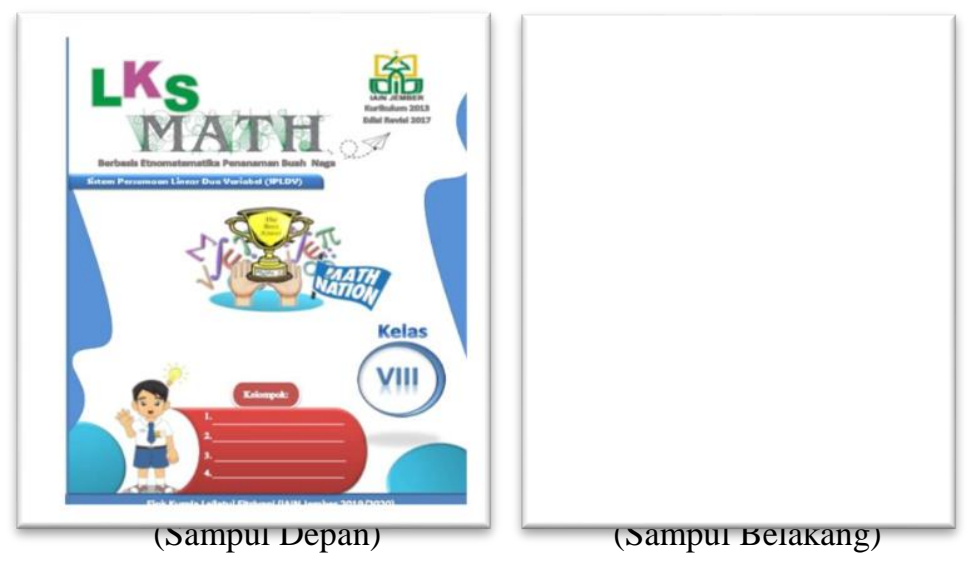

Gambar 4.9
Sampul LKS

Berdasarkan hasil validasi dari para ahli, secara garis besar desain cover menarik, keterpaduan warna cocok, gambar yang digunakan mendukung, ukuran normal, tata letak gambar sesuai, dan penelitian judul LKS yang dituliskan pada cover depan sesuai dengan muatan isi LKS. Karena setelah dilakukan validasi dan 
revisi oleh ketiga validator, maka sudah tidak ada masalah mengenai layout cover, sehingga sudah tidak terdapat kesalahan pada cover depan dan belakang.

\section{b. Kata Pengantar}

Pada kata pengantar ini memuat tentang ucapan rasa syukur atas terwujudkannya LKS matematika, ungkapan rasa syukur ini termuat dalam paragraf pertama dari kata pengantar. Inovasi tentang etnomatematika dalam dunia pendidikan, harapan peneliti tentang matematika ke depannya, kelebihan dan keurangan dalam penyajian LKS dan mengungkapkan tujuan terwujud pengembangan LKS berbasis problem based learning. Selain itu, peneliti menyadari akan kekurangan dalam penyajian LKS ini, maka dari itu peneliti tidak lupa mengharapkan saran, kritik dan masukan yang bersifat membangun dari berbagai pihak manapun terhadap hasil pengembangan LKS ini. Ucapan permintaan saran, kritik dan masukan ini termuat dalam paragrap akhir dari kata pengantar. Pada bagian bawah disertakan tempat, tanggal, bulan, tahun dan nama penyusun LKS. Untuk lebih jelasnya bisa dilihat pada lampiran produk pengembangan LKS (Lampiran 3).

\section{c. Over View}

Over view ini dibuat bertujuan untuk memberikan penjelasan kepada siswa mengenai kesesuaian aspek isi LKS dengan kompetensi inti, kompetensi dasar, indikator dan tujuan pembelajaran. Hal ini dicantumkan bertujuan agar siswa dapat memahami dibentuknya LKS ini berdasarkan kompetensi inti, kompetensi dasar, indikator dan tujuan pembelajaran yang diintegrasikan dengan model problem based learning. Para siswa dapat mengetahui tujuan pembelajaran pada LKS ini sehingga siswa dapat mencapai target dari tujuan pembelajaran. Over view ini dapat dilihat oleh siswa pada halaman "III dan IV". Untuk lebih jelasnya bisa dilihat pada lampiran produk pengembangan LKS (Lampiran 3).

\section{d. Daftar Isi}

Pada bagian daftar isi termuat informasi penting yang berguna untuk membantu pembaca agar mudah menemukan materi yang sedang dicari. Daftar isi ini terdiri dari nama sub bab disertai dengan halamannya. Pembaca dapat melihat daftar pustaka pada halaman "V". Untuk lebih jelasnya bisa dilihat pada lampiran produk pengembangan LKS (Lampiran 3).

\section{e. Fakta}


Fakta pada LKS ini memuat informasi tambahan mengenai etnomatematika penanaman buah naga. Informasi yang disajikan pada fakta ini berisi mengenai aktivitas penanaman buah naga mengenai siklus produktivitasnya. Informasi mengenai aktivitas penanaman buah naga ini diperoleh dari hasil observasi lapangan yang dilakukan oleh peneliti untuk mengetahui secara langsung. Adanya fakta ini bertujuan agar siswa mendapatkan wawasan pengetahuan yang luas mengenai etnomatematika buah naga. Fakta ini dapat dilihat oleh siswa pada halaman "VI". Untuk lebih jelasnya bisa dilihat pada lampiran produk pengembangan LKS (Lampiran 3).

\section{f. Detail Peta LKS}

Detail peta LKS ini berisi mengenai tampilan isi LKS secara keseluruhan. Tampilan pada detail peta LKS ini bertujuan agar siswa dapat mengetahui miniatur LKS secara detail. Mampu memberikan gambaran secara utuh mengenai bagianbagian yang terdapat di dalam LKS. Detail peta LKS ini dapat dilihat oleh siswa pada halaman "VII dan VIII". Untuk lebih jelasnya bisa dilihat pada lampiran produk pengembangan LKS (Lampiran 3).

\section{g. Peta Konsep}

Peta konsep dalam LKS ini memuat tentang pembagian materi dalam sub bab SPLDV. Peta konsep ini di buat untuk memberikan gambaran kepada siswa mengenai pembahasan materi SPLDV yang akan dipelajari oleh siswa. Harapan dengan menyajikan peta konsep ini siswa memiliki kesiapan belajar untuk memahami materi dalam sub bab SPLDV. Peta konsep ini dapat dilihat oleh siswa pada halaman "IX". Untuk lebih jelasnya bisa dilihat pada lampiran produk pengembangan LKS (Lampiran 3).

\section{h. Petunjuk Penggunaan LKS}

Petunjuk penggunaan LKS ini memuat gambaran secara ringkas mengenai muatan yang terdapat pada LKS berupa cara penggunaan LKS, cara mempelajari LKS produk pengembangan, aturan mengenai pengerjaan latihan soal pada LKS. Dengan adanya petunjuk penggunaan LKS ini, siswa, guru dan pembaca diharapkan mampu memaksimalkan belajarnya dalam menyelesaikan latihan soal pada LKS berbasis problem based learning. Untuk lebih jelasnya bisa dilihat pada lampiran produk pengembangan LKS (Lampiran 3).

Analisis pengembangan lembar kerja siswa (LKS) dengan konteks etnomatematika aktivitas 


\section{i. Kegiatan Pembelajaran}

Pada kegiatan pembelajaran pada LKS ini dibagi menjadi 4 sub bab. Adapun sub bab-sub bab pada materi SPLDV ini yaitu penyelesaian masalah menggunakan metode substitusi, metode eliminasi, metode gabungan dan aplikasi materi SPLDV dalam kehidupan sehari-hari. Pada masing-masing sub bab akan dijelaskan lebih lanjut mengenai definisi SPLDV, langkah-langkah penyelesaian menggunakan metode substitusi, metode eliminasi, metode gabungan serta menyajikan aplikasi dari materi SPLDV khususnya yang berkaitan dengan etnomatematika pada aktivitas penanaman buah naga. Selanjutnya guru membimbing siswa untuk menyelesaikan permasalahan aktivitas penanaman buah naga berbasis problem based learning yang disajikan pada LKS ini. Adapun langkah-langkah LKS pada aktivitas penanaman buah naga berbasis problem based learning yaitu:

\section{1) Latihan}

Pada latihan ini memuat gambaran permasalahan sehari-hari mengenai permasalahan aktivitas penanaman buah naga. informasi mengenai aktivitas penanaman buah naga ini diambil dari data observasi awal secara langsung kepada tiga petani yang dijadikan sebagai responden yang dapat memberikan wawasan terkait aktivitas penanaman buah naga secara detail dan lengkap. Pada latihan ini diharapkan siswa mampu mengamati permasalahan terkait aktivitas penanaman buah naga. Pada kegiatan ini, siswa harus meneliti dengan saksama mengenai gambaran permasalahan yang terjadi sehingga siswa mampu berpikir rasional dan dapat menyelesaikannya dengan tepat dan mudah.

\section{2) Lembar Jawaban}

Pada lembar jawaban ini siswa diminta untuk menentukan metode penyelesaian yang diinginkan. Kemudian siswa menyelesaikan permasalahannya sesuai langkah-langkah metode yang diinginkan. Adanya lembar jawaban ini diharapkan siswa dapat memiliki sikap aktif diskusi, bertanggung jawab, mampu berpikir rasional dan saling kerjasama dalam menyelesaikan tugasnya.

Selain itu siswa diminta untuk menyajikan penyelesaian dalam bentuk poster. Hal ini siswa diharapkan siswa bukan hanya menyelesaikan permasalahan saja, tapi siswa memiliki kemampuan untuk menyajikan data serta mempresentasikannya sehingga siswa benar-benar memiliki pemahaman yang matang mengenai jawaban yang telah disajikan. 


\section{j. Daftar Pustaka}

Daftar pustaka ini merupakan bagian terakhir dari LKS ini. Pada bagian ini memuat buku-buku yang dijadikan sebagai daftar rujukan pengembang dalam mengembangkan materi SPLDV dalam LKS ini.

\section{Tahap Uji Coba Produk (Validasi Produk)}

Data yang diujicobakan untuk dilakukan validasi dalam pengembangan ini yaitu LKS pada penanaman buah naga berbasis problem based learning dan soal post test. Selanjutnya LKS pada penanaman buah naga berbasis problem based learning dan soal post test ini akan divalidasi oleh tiga orang dosen sebagai tim ahli. Adapun tim ahli dosen tersebut yaitu ahli desain LKS, ahli konten matematika dan ahli pendidikan matematika. Tim ahli dosen inilah yang akan melakukan validasi terhadap produk pengembangan LKS ini untuk mengetahui kelayakan dari LKS pada penanaman buah naga berbasis problem based learning dan soal post test yang telah dikembangkan. Uji kelayakan ini dapat terlihat dari hasil instrumen penelitian berupa angket yang diberikan kepada tiga dosen sebagai tim ahli dari setiap bidangnya.

Adapun hasil validasi LKS pada penanaman buah naga berbasis problem based learning dan soal post test oleh tim ahli akan dipaparkan sebagai berikut:

1. Validasi Ahli Desain LKS

Validasi ahli desain LKS matematika dilakukan oleh Dr. Umi Farihah, M.M, M.Pd dengan memberikan penilaian, saran dan komentar untuk memperbaiki kekurangan terhadap tampilan pada LKS, fungsi bahan ajar dan manfaat bahan ajar. Adapun saran dan komentar yang diberikan yaitu:

a. Kata-kata kelompok pada sampul tidak jelas

b. Ukuran huruf sudah sesuai tetapi fontnya perlu diubah terutama halaman V-VII dan 2

c. Kata "Anda" dan "Kamu" sebaiknya konsisten pada kata "Kamu"

d. Banyak tulisan yang kabur terutama di halaman V sampai VII sebaiknya fontnya diubah, penelitian KI gunakan numbering

e. Ada beberapa soal yang sulit dipahami misalnya pada soal halaman 4 dan 6

f. Ada beberapa gambar yang masih kelihatan buram pada halaman VI, VII dan 4

2. Validasi Ahli Konten Matematika

Analisis pengembangan lembar kerja siswa (LKS) dengan konteks etnomatematika aktivitas 
Validasi ahli konten matematika dilakukan oleh Masrurotul Laily, M.Sc dengan memberikan penilaian, saran dan komentar untuk memperbaiki kekurangan terkait kriteria pertanyaan, aspek kontruksi dan aspek bahasa matematika pada LKS. Adapun saran dan komentar yang diberikan yaitu:

a. Mohon perbaiki contoh soal metode gabungan pada kalimat pertanyaannya

b. Notasi ilmiah dan konvensi satuan dicek lagi

3. Validasi Ahli Pendidikan Matematika

Validasi ahli desain LKS matematika ini dilakukan oleh M. Muklis, M.Pd dengan memberikan penilaian, saran dan komentar untuk memperbaiki kekurangan terhadap kesesuaian LKS pada kompetensi inti, kompetensi dasar, indikator, silabus dan tujuan pembelajaran. Adapun saran dan komentar tidak tertulis dengan catatan. Adanya melalui revisi kecil terkait penelitian tujuan pembelajaran.

\section{Tahap Revisi Produk}

Revisi produk merupakan proses akhir yang dilakukan oleh peneliti untuk melakukan perbaikan dengan memperhatikan saran atau komentar dari para ahli maupun pengguna peneliti yang akan melakukan perbaikan dan revisi terhadap instrument penelitian demi kesempurnaan dan kelancaran penelitian.

\section{SIMPULAN DAN SARAN}

Penelitian dan pengembangan ini mengacu pada rancangan penelitian dan pengembangan modifikasi dari model pengembangan Borg and Gall yang diadaptasi menjadi 5 fase. Adapun tahap-tahap model Borg and Gall yang digunakan yaitu (1) Tahap penelitian dan pengumpulan informasi awal, (2) Tahap perencanaan, (3) Tahap pengembangan produk, (4) Tahap uji coba produk, (5) Tahap revisi.

Hasil validasi LKS matematika berbasis problem based learning pada materi SPLDV yang dilakukan oleh tiga tim ahli maka LKS bisa digunakan dengan melakukan revisi terlebih dahulu tanpa dilakukan revisi selanjutnya.

\section{DAFTAR PUSTAKA}

\section{Books:}

Ah Sanaky, Hujair. (2015). Media Pembelajaran Interaktif-Inovatif. Yogyakarta: Kaukaba Dipantara.

Arifin, Zainal. (2014). Evaluasi Pembelajaran. Bandung: PT Remaja Rosdakarya. 
Sukardi. (2009). Evaluasi Pendidikan Prinsip \& Operasinya. Jakarta Timur: PT. Bumi Aksara.

Widoyoko, Eko Putro. (2014). Evaluasi Program Pembelajaran Panduan Praktis Bagi Pendidik dan calon Pendidik. Yogyakarta: Pustaka pelajar.

Purwanto, Ngalim. (2001). Prinsip-prinsip dan Teknik Evaluasi Pengajaran. Bandung: PT Remaja Rosda.

\section{Online Journal:}

Aprilianti, Indri, dkk. (2019). "Etnomatematika pada Aktivitas Petani Kakao Desa Temuasri Sempu Banyuwangi sebagai Bahan Ajar Siswa.” Saintifica 21, no. 1, 2.

Norsanty, Untari Octavia dan Chairani, Zahra. (2016). "Pengembangan Lembar Kerja Siswa (LKS) Materi Lingkaran Berbasis Pembelajaran Guided Discovery untuk Siswa SMP Kelas VIII.” Jurnal Pendidikan Matematika 2, no.1, 13.

Nurwani., Putra, Rizki Wahyu Yunian., dkk. (2017). "Pengembangan Desain Didaktis Bahan Ajar Materi Pemfaktoran Bentuk Aljabar pada Pembelajaran Matematika SMP." Numerical: Jurnal Matematika dan Pendidikan Matematika 01, no. 02, 9.

Budiaji, Weksi. (Desember, 2013). "Skala Pengukuran dan Jumlah Respon Skala Linkert (The Measurement Scale and The Number of Responses in Linkert Scale)," Jurnal Ilmu Pertanian dan Perikanan 2, no. 2, 128.

\section{Theses, Dissertation:}

Agustin, Mila Afriana. (2018). “Aktivitas Etnomatematika Petani Kopi di Daerah Sidomulyo Jember sebagai Lembar Proyek Siswa.” Skripsi, Universitas Jember.

Supriatna, Apit dan Nurcahyono, Novi Andri. (2017). "Etnomatematika: Pembelajaran Matematika Berdasarkan Tahapan-tahapan Kegiatan Bercocok Tanam." Seminar Nasional Pendidikan.

Hamzah, Amir. (2019). Metode Penelitian \& Pengembangan (Research and Development) Uji Produk Kuantitatif dan Kualitatif Proses dan Hasil. Malang: Literasi Nusantara. 